\title{
Palynological Studies of Maastrichtian to Paleocene Sediments Exposed at Okpekpe, Western Flank of Anambra Basin, Edo State, Nigeria
}

\author{
"IGBINIGIE, NS; AKENZUA-ADAMCZYK, AH \\ Department of Geology, University of Benin, Edo State, Nigeria \\ *Corresponding Author Email: nosa.igbinigie@uniben.edu
}

\begin{abstract}
Outcrop samples were collected at a road cut along Okpekpe road in the western part of the Anambra Basin with a view to establishing the age of the sediments and their depositional environment. These consist mainly of shales, sandstone, siltstone and heterolith. The samples were processed and analyzed using standard palynological procedures. Index fossils of stratigraphic significance were used for dating of the sediments. An extremely poor recovery of palynomorphs characterized by Acrostichum aureum, Laevigatosporites $s p$, Verrucatosporites sp, Cingulatisporite sornatus, Deltodosporasp, Lycopodium spp, Cyathidites minor, Echitricolporites triangulatus, Retitricolporites irregularis, Retitricolporites sp, Liliacidites sp, Longapertites marginatus, Longapertites sp, Erecipites sp., Monosulcites perspinosus, Retistephanocolpites williamsi, Echiperiporites estalae, Dodoneaviscosa, Echitriporite strianguliformis, Periretipollis spinosus, Marginipollis concinnus, Cupaniedites sp., Gleicheniidites senonicus Andalusiella polymorpha and Andalusiella $s p$ was noticed. A Maastrichtian-Paleocene age and a continental depositional environment were assigned to the sediments.
\end{abstract}

\section{DOI: https://dx.doi.org/10.4314/jasem.v22i10.05}

Copyright: Copyright $(92018$ Igbinigie and Akenzua-Adamczyk. This is an open access article distributed under the Creative Commons Attribution License (CCL), which permits unrestricted use, distribution, and reproduction in any medium, provided the original work is properly cited.

Dates: Received: 20 September 2018; Revised: 20 October: 2018; Accepted: 29 October 2018

Keywords: Palynology, Anambra Basin, Index fossils, Okpekpe, Mamu Formatiom.

The study area is located at latitude $\mathrm{N} 07^{\circ} 11^{\prime} 02.2^{\prime \prime}$ and longitude $\mathrm{E} 006^{\circ} 28^{\prime} 06.2^{\prime \prime}$. It is a road cut exposure of the Mamu Formation within the Benin Flank (western part) of the Anambra Basin. It occurs along Okpekpe Road in Etsako East Local Government Area of Edo State, Nigeria. The first area where intensive hydrocarbon exploration took place in Nigeria was the Anambra Basin. The basin has a sediment thickness of about 12,000 metres (Agagu and Adighije, 1983). The roughly triangular Anambra Basin Southern Nigeria covers about 40,000 sq km. The Southern boundary of the basin coincides with the northern boundary of the Niger Delta basin (Nwajide and Reigers, 1996). It is a symmetrical ridge stretching in sigmoid curve for over $500 \mathrm{~km}$ from Idah around the River Niger to Arochukwu in the Cross River (Arua, 1988). The origin and evolution of the Anambra Basin can be link to the origin of the Benue Trough. The Santonian deformation shifted depositional axis to Anambra Basin and Afipko syncline. (Ajakaiye and Burke, 1972) associated the evolution of the Benue trough with the rifting and breakup of Gondwana Super Continent leading to the separation of the Africa from South America in the Late Jurassic. (Burke et al., 1972) proposed a triple joint theory for the origin of the trough. They linked it to the ridge-ridge-ridge (r-rr) triple junction. The three arms of the junction are the
South America, the Gulf of Guinea and the Benue trough. According to Hoque and Nwajide, 1984), the evolution of the Benue trough was in four stages: rifting, trough, deformation and platform stages. The Mamu Formation consists of sandstones, shales, siltstones, coal seams and heteroliths. The sandstones have fine-medium grains brown-yellow in colour. The shales and mudstones are grey to black in colour. The coal seams vary in thickness from a few inches to twelve feet. The coals are of medium quality and are rich in resins and waxes. They have high ash content and display a rhythmic pattern of deposition. The sediments are shallow water deposits (Cratchley and Jones, 1965). Open strand plain and coastal plain environments have been inferred for this formation by the (Agagu et al., 1985) and (Nwajide and Reijers, 1996) respectively.

This study aims at applying palynology to decipher the age and depositional environment of the studied section. Palynology as a an aspect of biostratigraphy has proved to play important roles in deducing age of sediments, building sequence stratigraphic framework and reconstructing paleoenvironment (Morley, 1995; Ola-Buraimo and Akaegbobi, 2013a; Ayinla et al., 2013; Adeigbe et al., 2013) towards improving 
exploration and exploitation of oil and gas. The works of (Mebradu, 1988) is also relevant to this study.



Fig 1. Correlation Chart for Early Cretaceous strata in southeastern Nigeria (After Nwajide, 1990)

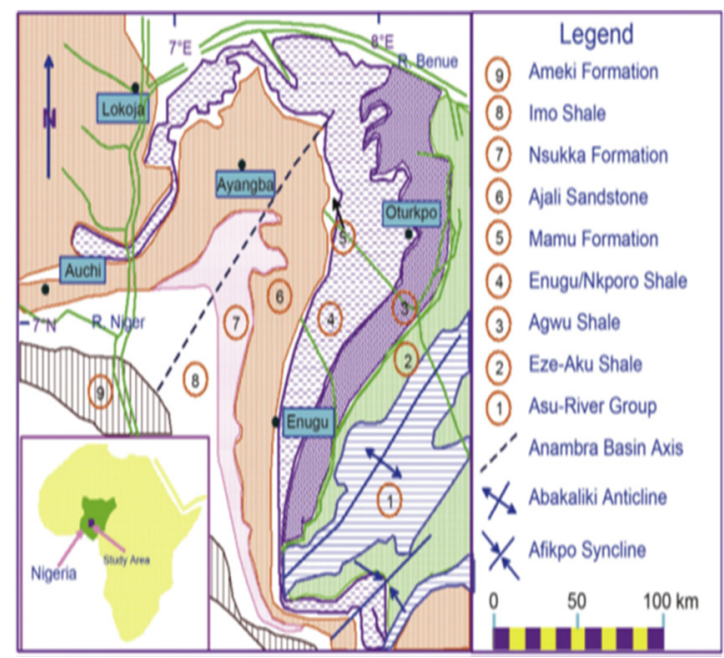

Fig 2. Geological map of the Anambra Basin showing location of study area (From Nton and Bankole, 2013).

\section{MATERIALS AND METHOD}

Standard palynological processing procedures (Faegri and Iversen, 1989; Wood et al., 1996) were employed for this purpose. Ten grams of each dry sample was crushed into small fractions. The samples were treated with dil $\mathrm{HCl}$ and $\mathrm{HF}$ to remove carbonates and silicates respectively. Concentrated $\mathrm{HNO}_{3}$ was used for oxidation and heated over Bunsen burner in a fume cupboard. $\mathrm{KOH}$ was introduced, allowed to stay overnight and stirred until a neutral solution was achieved. Ammonium hydroxide concentrate was added and diluted with water. At this stage separation of organic matter from inorganic was done by floating zinc bromide, $\mathrm{ZnBr}$. Slides were mounted using Norland adhesive mounting medium and dried. One slide per sample was analyzed under an optical microscope and the photomicrographs of wellpreserved palynomorph specimens were taken. Palynomorph identification was done using the works of (Germeraad et al., 1968) and (Evamy et al., 1978). The data was eventually plotted using StrataBugs software.

\section{RESULTS AND DISCUSSION}

The results of the five outcrop samples processed and analyzed for palynological studies are outlined and discussed in the following sections.

Sample 1: The palynomorphs recorded here are characterized by predominance of Cretaceous-Tertiary spores and pollens assemblage such as Deltodospora $s p$, Cingulatisporites ornatus, Cyathidites minor, Lycopodium sp., Erecipites sp., Longapertites sp., Liliacidites sp., Echitriporites trianguliformis, Marginipollis concinnus, Cupaniedites sp.,Dododnea viscosa, Retistephanocolpites williamsi, Periretipollis spinosus, Monosulcites perspinosus. The quantitative top occurrence of Cyathidites minor marks the top of Paleocene boundary and the presence of Echitriporites trianguliformis, Retistephanocolpites williamsi and Longapertites sp indicate Maastritchian age.

Sample 2: The presence of Echitricolporites triangulatus, Deltodospora sp, Cingulatisporites ornatus, Erecipites sp, Cupanieidites, Gleicheniidites senonicus, and Leoitriletessp with spot occurrence of pteridophyte spores such Laevigatosporites $s p$ indicate Maastrichtian to Paleocene. The age confirmation was based on the presence of Deltodospora sp and Gleicheniidites senonicus which are palynomorphs of Late Cretaceous.

Sample 3: Paucity of marker palynomorphs was observed here. Forms like Longapertites marginatus, Cyathidites sp, Verrucatosporites $s p$ and Zonocostites ramonae were however recorded.

Sample 4: The presence of Andalusiella polymorpha, Andalusiella sp, Leoitrietes $s p$ with minor occurrences of pteridophyte spores such as Verrucatosporites $s p$ and Laevigatosporites sp indicate Maastrichtian to Paleocene age.

Sample 5: The presence of Cyathidites $s p$, Verrucatosporites $s p$ and Retitricolporites $s p$ without any distinct marker species. 


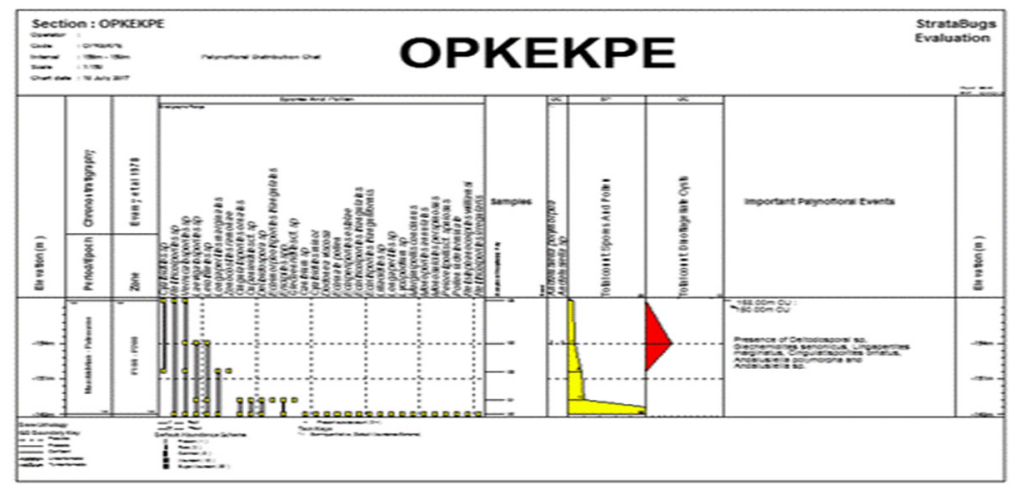

Fig 3. Palynomorph distribution chart of the studied interval

Age: The assemblage of marker palymorphs recorded within the studied section reflects Maastrichtian to Paleocene age.

Depositional environment: The presence of terrestrial pollens and spores such as Cingulatisporites ornatus, Erecipites sp., Longapertites sp., Liliacidites sp., Lycopodium sp., Gleicheniidites senonicus, Cyathidites minor, Echitriporites trianguliformis, Cupanieditessp., Dododneaviscosa, Marginipollis concinnus, Retistephanocolpites williamsi, Deltodospora sp., Monosulcites sp. indicate a continental depositional environment

Conclusion: The palynological analysis of the studied section was used to determine the age and depositional environment of the studied section. Presence of diagnostic palynomorphs aided in the establishment of age and depositional environment. Conclusively, the sediments were deposited in a continental environment and of Maastrichtian to Paleocene age.

\section{REFERENCES}

Adeigbe, OC; Ola-Buraimo AO; Moronhunkola, AO (2013). Palynological characterization of the Tertiary offshore Emi-1 well, Dahomey Basin, Southwestern Nigeria. Inter. J. Sci. Technol. Res. (2) $1: 58-70$

Agagu, OK; Adighije, CI. (1983) Tectonic and Sedimentation Framework of the Lower Benue Trough, Southern Nigeria. J. Afr. Earth Sci. 1: 267-274.

Arua, I (1988). Episodic sedimentation: an example from the Nkporo Shale (Campano Maastrichtian), Nigeria. . J. Afr. Earth Sci. 7: 759726.

Ayinla, HA; Ola-Buraimo AO; Adeigbe, OC; Bankole, SA; Adebowale, M. (2013). Biostratigraphy and high resolution paleoenvironmental reconstruction of part of Kemar-1 well, Bornu Basin, Northeastern Nigeria. J. Res. Environ. Sci. Toxic. 2(3): 5363.

Burke, K (1972). Geological history of the Benue valley and adjacent areas In: Dessauvagie, TFJ; Whiteman, AJ, (ed.), African geology, Ibadan, Nigeria, Univ. Ibadan: 187 205.

Evamy, DD; Haremboure , J; Kamerling, P; Knaap, WA; Mollot, FA; Rowlands, PH (1978). Hydrocarbon habitat of Tertiary Niger Delta. AAPG Bull. 62: 1-39.

Faegri, K; Iversen, J (1989). Textbook of Pollen Analysis. Faegri K, Kaland PE, Krzywinski K, editors. New York: John Wiley \& Sons; 328.

Germeraad, JJ; Hopping, GA; Muller, J (1968). Palynology of Tertiary sediments from tropical areas. Rev Palaeobot Palyno 6: 189-348.

Hoque, M; Nwajide, CS. (1984). Tectono-sedimentological evolution of an elongate intracratonic basin (aulacogen): The case of the Benue Trough of Nigeria. Nig. J. Min. Geol. (21) 19-26.

Mebradu, S (1988). Stratigraphy and Palynology of Auchi sediments, Southwestern Nigeria. Geophytology. 18 (1): $41-46$. 
Morley, RJ (1995). Biostratigraphic characterization of systems tracts in Tertiary sedimentary basins. Indonasian Petroleum Association, Proceedings of the International Symposium on sequence stratgraphy in SE Asia, 49-71.

Murat, RC (1972). Stratigraphy and paleogeography of the Cretaceous and Lower Tertiary in southern Nigeria. African geology, 251-266.

Nton, ME; Bankole, SA (2013). Sedimentological characteristics, provenance and hydrocarbon Potential of post Santonian sediments in Anambra Basin, southeastern Nigeria. RMZ-Materials and Geo-environ. J. 60(1), 47-66.
Nwajide, CS; Reijers, TJA. (1996). The Geology of the southern Anambra Basin, In: Reijers, TJA (ed.), Selected chapters in Geology, sedimentary geology and sequence stratigraphy of the Anambra Basin, SPDC reprographic unit, Warri, 133-148.

Ola-Buraimo, AO; Akaegbobi, IM (2013b). Palynological and paleoenvironmental investigation of the Campanian-Lowermost Maastrichtian Asata/Nporo Shale in the Anambra Basin, southeastern Nigeria. British J. Appl. Sci. Technol. 3(4): 898-915. 